\title{
Polemics on the Etiology of Juvenile Delinquency: A Review of Some Multiple-Perspective Attacks on Travis Hirschi's Social Bonding Theory
}

\author{
J Forbes Farmer \\ Department of Criminal Justice, Franklin Pierce University \\ 40 University Drive \\ Rindge, New Hampshire, USA 03461 \\ Tel: 603-899-4216 E-mail: Farmerjf@Franklinpierce.edu
}

Received: August 21, 2018 2018

doi:10.5296/iss.v6i2.13746
Accepted: September 2, 2018 Published: October 8,

URL: http://dx.doi.org/10.5296/iss.v6i2.13746

\begin{abstract}
Influenced by Thomas Hobbes's Leviathan (1957 [1651]) and Emile Durkheim's Le Suicide (1966 [1897]), criminologist Travis Hirschi wrote Causes of Delinquency (1969) in which he hypothesized that the more a juvenile is bonded to conventional society, the less likely he will become delinquent. Hirschi described four elements of the "social bond" (attachment, commitment, involvement and belief) and detailed the methodology he used to develop what is commonly referred to as "social bonding theory." Although this enduring classic work has been seriously tested and highly praised for almost five decades for its classic contribution to the study and prevention of delinquency (and crime), it has also been sharply criticized from many theoretical and methodological perspectives. This paper provides an identification and review of several of those attacks.
\end{abstract}

Keywords: Travis Hirschi, juvenile delinquency, social bonding theory, control theory 


\section{Introduction}

The more weakened the groups to which [the individual] belongs, the less he depends on them, the more he consequently depends only on himself and recognizes no other rules of conduct than what are founded on his private interests. (Durkheim, 1966, p. 209)

Control theories assume that delinquent acts result when an individual's bond to society is weak or broken. (Hirschi, 1969, p. 16)

To prevent and control delinquency, we must first know something about the nature of delinquency and the dimensions of the problem. (U. S. President's Commission on Law Enforcement and Administration of Justice, 1967, p. 55)

The focus of this article is on some criticisms of Travis Hirschi's social bonding theory that was developed and outlined in his Causes of Delinquency (1969), a book that led Jensen (2003) to say that "Hirschi established his reputation as the preeminent social control theorist of the 20th century" (p. 6). Rankin and Kern (1994) noted that Hirschi's 1969 theory "is relatively explicit, well developed, and amenable to empirical tests" (p. 495). Shortly after Causes of Delinquency was published, scholars (Hindelang, 1973; Gibbons, 1979) wrote that Hirschi's research into how social bonds to society affected a juvenile's entry into crime would be an enduring contribution to delinquency and family dynamics because of the lucidity of its concepts and the strong empirical connections between Hirschi's theoretical propositions and research. This prediction was prophetic; the book has dominated criminological research for almost five decades. Yet the path to theoretical stature was fraught with many scholarly attacks at a time when the United States was faced with a serious delinquency problem that challenged its criminal justice institutions.

The perpetuation of criminal justice institutions is predicated on the assumption that juvenile delinquency, crime and deviance will always be a global and society-threatening problem and there will always be conformity. And just as assuredly, one of the most vexatious problems social scientists have is determining and defending the philosophical basis of this assumption and their explanation for it. Those interested in reducing crime and delinquency might ask one of two questions: (1) Why do people commit crimes? or (2) Why do people not commit crimes? Discovering the complex answers to these questions is very important to criminal justice practitioners, and they rely on criminologists to do this for them. It seems obvious the incidence of crime and delinquency could be lowered if factors leading to crime were lowered, and that increasing the factors leading to conformity (not committing crimes) would increase conformity. Thus, a positive (direct) correlation in both cases would be desirable. Unfortunately for criminal justice practitioners, the criminologists' exploration into the depths of this phenomenon is often riven with theoretical rivalry, mystification, complexity and doubt. Even the most perspicacious among the theorists cannot agree on one single explanation of crime, delinquency or conformity.

Whether delinquent or conformist behaviors are socially learned (Akers, 1973; Sutherland, 1934; Cressey, 1962; Sykes \& Matza, 1957), or innate (Durkheim, 1965 [1912]; Hobbes, 
1957 [1651]; Hirschi, 1969), or a result of strain (Merton, 1938; Agnew, 1992), or due to the distribution of power (Chambliss, 1976; Turk, 1969), these behaviors are facts of life and will forever be researched, analyzed and debated. The focus of criminology and policy developers is mostly on the threatening kind of deviance, and as scholars (Rosenfeld, 2018; Tibbetts, 2018) have stated, crime is an inherently dynamic phenomenon that traverses time and place. To put it another way, crime and delinquency are relative (Felson \& Eckert, 2018; Posick, 2018). Deviance, of course, need not always be negative or destructive. Societies need deviants to break from the complacency of conformity. Deviance often leads to positive results through invention, creativity, political dissent or even the overthrow of repressive regimes. Nevertheless, crime, delinquency and deviance are social issues that can be either increased or decreased through the mechanisms of social control.

Travis Hirschi (b. 1935 - d. 2016), like some other control theorists, generally followed Hobbesian (1957) logic and the Durkheimian (1967) idea that people are innately selfish, self-centered and greedy. Unlike Hobbes who believed that we obey society's rules because we live in constant fear of everyone else (Tibbetts, 2019; Hill \& Pollock, 2015), Hirschi thought there "was more to conformity than fear" (p. 5). Everyone has temptations and could commit crimes (Felson \& Eckert, 2018), and to prevent people from committing crimes they must be socially controlled through the development of governmental rules (Tibbetts, 2019) and conformist ties to society. The ties are an important deterrent to delinquency because people do not want to jeopardize their bonds to people or institutions (Posick, 2018).

Hirschi, the scholar most responsible for establishing control theory in criminology (Kempf, 1993; Posick, 2018; Jones, 2017; Tibbetts, 2019; Vold \& Bernard, 1986), has been described as one of the most enduring and influential criminologists of his time despite the title of his seminal Causes of Delinquency (1969) and the focus of this paper. The title is misleading for two reasons. First, by "causes" he really meant "correlates." Second, his intent was not to address the reasons people were delinquent, but rather why they were not. As Hirschi (1969) stated, “The question 'Why do they do it?' is simply not the question the theory is designed to answer. The question is 'Why don't we do it?' There is much evidence that we would if we dared" (p. 34). Most criminologists agree that Hirschi's theory can be applied to any type of criminal or deviant behavior, not only delinquency (Akers, Sellers \& Jennings, 2017; Tibbetts, 2018). But the following discussion is focused specifically on Hirschi's original and insightful theory about juvenile delinquency, not more serious juvenile or adult crime.

This article provides a review of, and comments on, some of the multiple-perspective criticisms that scholars have leveled against eight areas of Hirschi's (1996) social bonding theory. The eight areas identified are: (1) the basic assumptions, (2) the "social bond" constructs, (3) the research methodology, (4) the exclusion of women from the sample and the neglecting of race, religion and the influence of delinquent peers, (5) the social class variable, (7) the type of delinquency studied and (8) the missing explanation for bond development and severance. A good number of these criticisms came from social learning theorists like Akers (1973) and strain theorists like Agnew (1984, 1985, 2005) who represent very different epistemological traditions, but proponents of other perspectives (e.g., conflict, feminist and developmental) weighed in as well. Many of these criticisms provided 
challenges for Hirschi who spent years addressing them.

\section{Basic Assumptions of Social Bonding Theory}

The structure of Hirschi's original theory was predicated on at least four assumptions. The first was, as Hirschi (1969) stated, "We are all animals and thus naturally capable of committing criminal acts" (p. 31). However, unlike other control theorists who posit that there is a universal, natural motivation to push against societal rules and break them (Akers et al., 2017; Cullen, Agnew \& Wilson, 2014; Erickson, Crosnoe \& Dornbusch, 2000), Hirschi believed that the motivation could be individually modified (Akers, 2000). The second assumption was that societal members must be restrained, or somehow controlled, if repression of delinquency was to be obtained (Krohm \& Massey, 1980). Delinquency, thus, resulted from the absence or deficiency of some control mechanism (Posick, 2018). As Akers et al., (2017) said, "We would all break the law if we could get away with it" (p. 118).

The third assumption, and another one introduced by Durkheim (1966, p. 18), was that delinquency could be expected. As Hirschi (1969) stated, "Given that man is an animal, 'impulsivity' and 'aggression' can also be seen as natural consequences of freedom from restraints" (p. 18). Another assumption was that people are tied together in a social order by "the existence of a common value system within society or group whose norms are being violated" (Hirschi, 1969, p. 23). It is the social bonds, or a person's entwinements in relationships with others (Felson \& Eckert, 2018, p. 69), that Hirschi believed are necessary to tie people together in a way that they understand and accept as social norms. Thus, Hirschi proposed that delinquency and social bonds are inversely related. As Hirschi (1969) wrote,

"The norms of society are by definition shared by the members of society. To violate a norm is, therefore, to act contrary to the wishes and expectations of other people. If a person does not care about the wishes and expectations of other people, that is, if he is insensitive to the opinion of others - then he is to that extent not bound by the norms. He is free to deviate" (Hirschi, 1969, p. 18).

\section{Areas of Criticism of Social Bonding Theory}

\subsection{The Assumptions}

Although influenced by Thomas Hobbes, the seventeenth-century English intellectual, philosopher and scientist who wrote Leviathan (1651), Hirschi clearly questioned the Hobbesian assumption that crime was due entirely to inherent impulse (Akers et al., 2017; Empey, 1978). Hirschi believed that the "normality of the mind" assumption of Hobbes had to be modified to include inducements to delinquency (Akers et al., 2017; Akers, 2000), and this involved self-seeking, cost-benefit rationality (Jones, 2017). Some criminologists, especially social learning theorists, believed that Hirschi's assumption relied too heavily on Hobbesian logic. Gibson (1970), who set up criteria for evaluating criminological theories, claimed that Hirschi was "stuck in the eighteenth century" (p. 452) and seemed oblivious to the more advanced and modern psychological research and theory which was 
criminologically relevant.

Hirsch reduced all delinquency theories to variations of strain, cultural deviance and social control. There were some learning theorists (Lemert, 1970) who believed that Hirschi was far too reductionistic. Hirschi's perspective also involved, "pitting a psychological explanation of crime against sociological theories" (Gibson, 1970, p. 452). Hirschi did not really find "causes" of delinquency, but simply isolated associations between self-reported delinquency, facts and attitudes. Akers (1973), Akers et al. (2017) and Lemert (1970) pointed out that Hirschi's (1969) Causes of Delinquency showed very little appreciation for the individual motivation to deviance. They claimed Hirschi took for granted that the motivation was the same for everyone and that all people need restraint to prevent acts committed out of greed and selfishness set loose by a free rein.

\subsection{The Validity of the Constructs of Attachment, Commitment, Involvement and Belief}

Another area of criticism regarded Hirschi's construct validity. Based upon the idea that the social order could be taken for granted (Hirschi, 1969, p. 23), Hirschi proceeded to introduce four key interrelated elements found within the juveniles that he believed composed the social bond 'to 'informal' social institutions such as family, school, and education. These would be similar to the inculcation promoted by Durkheim" (Hill \& Pollock, 2015, p. 784.) that established social conformity and served as primary inhibitors (Intravia, Jones \& Piquero, 2012) to social bond violations (Chui \& Chan, 2012). Some theorists (Akers, 2000; Akers et al., 2017) believed that Hirschi's operationalization and measurement of the four social bond elements as listed (Figure 1) and outlined below were very clear. However, there has been considerable criticism regarding the validity of the four constructs.

\begin{tabular}{|cccc|}
\hline $\begin{array}{c}\text { Social-Psychological } \\
\text { Source }\end{array}$ & $\begin{array}{c}\text { Elements of the } \\
\text { Social Bond }\end{array}$ & Outcome \\
Parents, peers, & (1) Attachment \\
schools & $\rightarrow \quad \begin{array}{c}\text { (2) Commitment } \\
\text { (3) Involvement } \\
\text { (4) Belief }\end{array}$ & $\rightarrow$ & $\begin{array}{c}\text { Juvenile Delinquency } \\
\text { or Conformity }\end{array}$ \\
& & \\
\hline
\end{tabular}

Figure 1. Model of Hirschi's social bonding theory as depicted in Causes of Delinquency (1969).

\subsubsection{Attachment}

The first element, "attachment," was measured by assessing the degree of affection and respect between juveniles and their significant others; parents, teachers and friends. Scholars claim that Hirschi believed this to be the most important of the bonds because of its significance to the internalization of norms of conformity (Tibbetts, 2019). In this regard, the 
attachment to parents was most important because if the attachment bond was strong then the juvenile did not want to disappoint them (Cullen, Agnew \& Wilcox, 2014). But, as scholars (Tibbetts, 2019; Gibbons \& Krohn, 1991) have pointed out, a criticism of Hirschi's idea here is that "the effect of attachment on crime depends on to whom one is attached" (Tibbetts, 2019, p. 176).

Positivists believed that Hirschi was vulnerable to the charge that he had not collected reliable information for his measurement of "attachment." When it came to "peer effect" on delinquency, Hirschi found a strong relationship. Chui and Chan (2012), however, believed Hirschi's model assumed a spurious relationship. Shoemaker (1984) made this very point when he accused Hirschi of not considering the cultural and historical values and conditions which influence the strength of attachment to conformity. Social learning theorists believe that Hirschi should have measured perceptual measures of peer deviance as opposed to relying on self-reports (Boman, Ward, Gibson \& Leite, 2012).

Having made the assumption about social order, the learning theorists believed he was obligated to prove the representative conventionality of the teachers, friends and parents. That is, how did Hirschi measure or know that these people influencing the youth were, in fact, supportive of the "conformist" social order? Several criminologists agree that he failed to address this (Linden and Hackler, 1973; Conger, 1976; Krohn \& Massey, 1980; Agnew, 1984). They thought this was a crucial shortcoming because it weakened Hirschi's argument that people had to be controlled or they would deviate. Since the conventionality proof is nonexistent, they said, Hirschi should have disproved the fact that non-conventionality could be the result of attachment to significant others who were deviant.

Agnew (1984), a strain theorist, and others believed that this conventionality argument that Hirschi tried to make got into serious trouble when Hirschi measured the juveniles' attachment to school. Krohn and Massey (1980) agreed that this presented grave conceptual difficulties. At one point, Hirschi was interested in the youth's ties with school personnel (Hirschi, 1969, p. 123). This was compatible with his ideas of "attachment", but before that he had asked the students if they liked school (Hirschi, 1969, p. 121). Krohn and Massey (1980) stated that unless the assumption is made that institutions can be treated as people, the measure of affection to school was a departure from his definition of "attachment" which had to do with significant others. Hirschi was vague in the discussion that followed and it was uncertain how the social bond between the youth and the school would get worked out (Krohn \& Massey, 1980).

When Hirschi connected conventionality to the need for autonomy, the youth-school connection got confusing (Agnew, 1984). The need for autonomy was taken as an indicator of low social control. The denial of this need, according to Hirschi (1969), "leads to the reduction in other types of social control" (Agnew, 1984, p. 220); namely ties to significant others in school. But, the actual measurement of this was done through student grades and academic ability. Since Hirschi failed to make a case for affective attachment, as grades lack an affective component (again, according to his definition of attachment), it seemed to Agnew (1984) that the issue of low social control measured through grades and boredom would be 
best discussed under "commitment."

\subsubsection{Commitment}

The second element, "commitment," was defined as the "rational component in conformity" (Hirschi, 1969, p. 20) and was based on a juvenile's obeying of society's rules and an investment in conventional society because of a fear of the consequential damage to the bonds (Posick, 2018) and to personal interests (Lanier \& Henry, 2010). Thus, "the greater the commitment, the more one risks losing by non-conformity" (Akers, 2000, p. 107). But according to Wiatrowski (1978), Hirschi assumed that the juvenile's relationship to society was fixed in interaction with primary groups. Wiatrowski argued that the level of social bond can change as structural factors, like school tracking and parental social background, change over time. When these change, the juvenile's commitment to attending college and obtaining a high-status occupation can change and thus alter the level of delinquent activity (Wiatrowski \& Anderson, 1978; Krohn \& Massey, 1980).

\subsubsection{Involvement}

The third element, "involvement," was defined as "engrossment in conventional activities" (Hirschi, 1969, p. 20). Hirschi's idea was that adolescents who are kept busy by participating in conventional activities could be inhibited from delinquency (Tibbetts, 2019) because more time spent in one activity meant less time in the other (Lanier \& Henry, 2010). But Wong (2005) had two problems with this concept. He believed Hirschi assumed that delinquency was time-consuming, and he thought Hirschi assumed delinquency only took place in a delinquent context. Krohn and Massey (1980) believed that Hirschi should have combined social bond elements of commitment and involvement because they were codependent. To "put it another way," said Gibbons (1994), "involvement appears to be the behavioral side of commitment; hence these are two aspects of the same thing" (p. 34). As it turned out, "involvement" was the only element of the social bonds that, when weak, did not lead to a high probability for delinquency.

\subsubsection{Belief}

The fourth element, "belief", referred to the respect for, and endorsement of, rules of good conduct and the established law. It referred to the conviction that conventional behavior and respect for its values are necessary and important for an orderly society (Lanier \& Henry, 2019). Felson and Eckert (2018) claimed that Hirschi thought that delinquents and nondelinquents had the same common value systems about crime being bad (Lanier \& Henry, 2010), but that delinquents had weaker commitment to the rules. Hirschi (1969) wrote, "The less a person believes he should obey the rules, the more likely he is to violate them" (p. 26). Felson and Eckert (2018) also believed Hirschi was unclear as to how he measured the strength of the commitment towards these rules.

All of this led Tibbetts (2019) and Akers (2000) to point out that "the components of the social bond may predict criminality only if they are defined in a certain way" (Tibbetts, 2019, p. 176). Adler and Laufer (1995) suggested Hirschi had a conceptual problem by not putting "theoretical limits on the types of aspirations or ambitions that would qualify as either 
delinquency-inhibiting commitments" (p. 154) or attachments. It is also the case, as pointed out by Gibbons and Krohn (1991), that Hirschi failed to "specify a causal order among the elements of social bond" (p. 103) although he did suggest that "attachment" should be ordered first. Determining the correct causal order of the elements was not possible they said with Hirschi's use of a "one point at a time" survey.

\subsection{Methodology}

\subsubsection{Self-reported Cross-sectional Data}

The next major criticism involved Hirschi's method of data collection and the way he presented his findings. Hirschi tested his theory in 1965 by administering a survey to 3,605 adolescent males in a stratified random sample. Agnew (1985) claimed that Hirschi's use of anonymously self-reported cross-sectional data, as opposed to longitudinal data, was a major shortcoming and reduced the overall importance of the theory. Gibbons (1994) was also critical of the use of a questionnaire. He claimed that when the juveniles choose from a set of responses, the results could have been inaccurate because the choices were not "sophisticated enough to capture their [juveniles'] actual feelings or perceptions" (p. 77).

Gibson (1970) wrote in a book review of Causes of Delinquency that Hirschi's data was collected "in a thoroughly bad manner" (p. 453) and did not recommend the book. He wrote that Hirschi "is entitled to his opinions and theories, but it would be very rash for anyone to base any firm conclusion on such data" (Gibson, 1970, p. 453). According to Gibson (1970) and Box and Ford (1971), the research would have been more scientific had Hirschi conducted confidential personal interviews instead of relying on a self-administered questionnaire. Had he done that, said Box and Ford (1971), the criticism of his methodology "would not be warranted" (p. 43).

\subsubsection{Anonymity}

Hirschi claimed that his questionnaire was anonymous. The instructions read "no one at the school will know how you mark your answers" (Hirschi, 1969, p. 248). Hirschi described how, while no one at the student's school would see the answers, they would be taken to a university computer center. Hirschi needed the names so he could go back and get students to finish uncompleted questionnaires. It was hard for Gibson (1970) to believe that students at this age were not suspicious of the anonymity claim while at the same time being asked for their name. Confidential interviews would have controlled for this. The children were being asked for criticisms of their teachers, crimes (the children) had committed and much more sensitive, personal data (Hirschi, 1969, pp. 248-299). Hirschi tried to explain away the children's skepticism, but failed. Box and Ford (1971) wrote that Hirschi's data collection method left him open to attack because the research results could be skewed by differences in the rate of concealment and exaggeration between social classes.

\subsubsection{The Questionnaire and Parental Permission}

According to Gibson (1970), Hirschi's (1969) fifty-one page questionnaire was also seen as being too long, the nature of it a "disaster" (p. 452) and the way it was presented to the school 
children was "completely uncontrolled" (p. 452). Some students completed the questionnaire in one long sitting while others took several days. There were even some children, as mentioned before, who had either turned it in unfinished or had made a mess out of it and were asked to complete it "seriously" (Gibson, 1970, p. 453). This problem was compounded by the fact that Hirschi identified a population of 5,545 (Hirschi, 1969, p. 36), but the response rate dropped by 26.5 percent when the parental permission, required by the school, was not forthcoming. He was widely criticized for his final sample (Bernard, 1984; Jones, 2017) that had a shortage of delinquents, serious or otherwise.

For white boys, the category within which he studied the class-delinquency association, Hirschi's response rate dropped to 63 percent. Bytheway and May (1971) believed that those white boys who were lost from the study because they did not get parental permission would have probably been drawn from low status groups and from groups whose parents knew of their delinquency and did not want them identified.

\subsubsection{Inferential Strength}

It has been said that the social bonding theory had a better reputation for the consistency of Hirschi's insights than because of the strengths and inferential power of his results (Agnew, 1985; Kempf, 1993; Empey, 1978). But it served as a decent model (Akers et al., 2017). While attachment, belief, commitment and involvement (the four elements of Hirschi's theory) have all been shown to be more or less related to delinquent behavior, they accounted for only a limited examination of the overall impact of these variables or the individual impact of each component. There never was a multiple correlation computed involving the four elements, but Hirschi did compute correlations involving some of the elements and accounted for only between 20 (Krohn \& Massey, 1980, p. 532) and 25 (Empey, 1978) percent of the variation between delinquents and nondelinquents. This meant that "many of the factors contributing to delinquent behavior remains unexplained" (Empey, 1978, p. 239).

Also, critics claimed that Hirschi found himself unable to state which element would be the best predictor of delinquency although, according to Krohn and Massey (1980), the theory indicated that intercorrelations and positive correlations could have been found. Instead, said Gibson (1970), most of Hirschi's findings were presented as percentage tables with levels of significance missing. And upon such weak research, wrote Gibson (1970), Hirschi made such statements as "there are no groups of substantial proportions in American society whose values are neutral with respect to crime" (Hirschi, 1969, p. 230).

\subsection{The Exclusion of Women and the Neglecting of Race, Religion and Delinquent Peers}

\subsubsection{Women}

Hirschi (1969) thought that social controls were gender-neutral (Chui \& Chan, 2012), so Hirschi dropped women from his study. This raised a major criticism from Özbay and Özcan (2008) and feminists like Chesney-Lind (1997) who believed that by excluding women Hirschi's theory could not be generalized to female delinquents. Messerschmidt (1993) wrote that this omission rendered Hirschi's theory "incapable of deciphering the gendered nature of crime" (p. 3). In a footnote, Hirschi (1969) wrote "In the analysis which follows, 'non-Negro' 
becomes 'white', and the girls disappear. Since girls have been neglected for too long by students of delinquency, the exclusion of them is difficult to justify" (pp. 35-36). That's basically all Hirschi said on the topic and focused his study on boys. Even though there is less female than male delinquency, the critics claimed Hirschi missed a good opportunity to show that traditional sex roles help inhibit delinquency among young women (Bainbridge \& Crutchfield, 1983). He could have shown that girls might simply be more closely supervised by parents and under more powerful direct control, especially in patriarchal families (Hagan, 1989).

Krohn and Massey (1980) also suggested that the elements of social bond might better explain female delinquency better than male delinquency. Morris (1964) suggested before Hirschi did his research that economic achievement (measured through some school items) would best explain male delinquency while affective measures resulting in interpersonal relationships could better explain female delinquency. There has, since Hirschi's study came out, been considerable support for the necessity of including females in delinquency studies (Chui \& Chan, 2012; Dukes \& Stein, 2001; Chesney-Lind \& Shelden, 2004; Özbay \& Özcan, 2008), but Hirschi took the expedient route by excluding them.

\subsubsection{Delinquent Peers}

Although Hirschi conceded that he underestimated the importance of delinquent peers, some criminologists (Pratt, Gau \& Franklin, 2011; Zaidi, Couture-Carron \& Maticka-Tyndale, 2016; Jensen, 2003; Gibbons, 1994) criticized him for neglecting the significant role of this group on the development of delinquency. They believed Hirschi placed too much reliance on the juvenile's participation with conventional peers. Yet, Hirschi (1969) himself proposed that the approval of delinquent peers must be considered (Akers et al., 2017). Akers (2000) thought that Hirschi unanticipatedly "found delinquency to be most strongly related to associations with delinquent friends" (p. 108). For others (Boman, et al., 2012; Vetter and Silverman, 1986), this underestimation of the significance of peers and the over-reliance upon conventional participation was also due to Hirschi's assumptions regarding natural motivation and a common set of values. Little (1983) wrote that the "theory looks at the other side of the deviancy coin and might be considered more a theory of conformity rather than one of deviance" (p. 18).

\subsubsection{Race}

Hirschi was also criticized (Lilly, Cullen, \& Ball, 2011; Unnever, Cullen, Mathers, McClure \& Allison, 2009) for not only neglecting the importance of race and the discrimination experience of African Americans as it related to delinquency, but also for concluding that discrimination did not contribute significantly to delinquency (Gibbons \& Krohn, 1991). Hill and Pollock (2015) noted that Hirschi only addressed the racial differences in black/white academic achievement to explain the differences in their delinquency. Empey (1978) noted that Hirschi failed to address the fact that Black adolescents are more likely to report their acts of violence. Hirschi (1969) stated that "there is no reason to believe that the causes of crime among Negroes are different from those among whites" (p. 79). He also wrote "we need not study [African American] boys to determine their delinquency" (p. 80). According 
to Unnever et al. (2009), "Hirschi missed a historic opportunity to focus the attention of a generation of criminologists on how the unique experiences of African Americans may shape their criminality" (p. 378).

\subsubsection{Religion}

Hirschi's lack of attention to religion was also noted (Akers, 2000; Cretacci, 2002; Hill \& Pollock, 2015; Krohn \& Massey, 1980). Hill and Pollock (2015) believed this omission was intentional and that Hirschi, anticipating criticism for this, tried to cover himself with more research (Hirschi \& Stark, 1969). In this paper they argued that there would be little reason religion and church attendance would be related to delinquency because they fail "to instill in its members love for their neighbors and because belief in the possibility of pleasure and pain in another world cannot now, and perhaps never could, compete with the pleasures and pains of everyday life" (Hirschi \& Stark, 1969, pp. 212-213). Krohn and Massey (1980) argued that Hirschi should have addressed religion and that it should be included in a modified version of Hirschi's theory. Cretacci (2002) also believed Hirschi should not have omitted it and included religion in his expansion of Hirschi's theory.

\subsection{Social Class}

Empey (1978) noted that delinquency literature during the 20th century mostly pressed the notion that there are competing class cultures in our society that are related to both lower and middle class delinquency. But many empirical investigators (i.e., Akers, 1964; Bytheway \& May, 1971; Tittle, Villemez \& Smith, 1978) found, as did Hirschi, that social class is not a good predictor of delinquency. Hirschi (1996) wrote, "While the prisons bulge with the socioeconomic dregs of society, careful quantitative research shows again and again that the relation between socioeconomic status and the commission of delinquent acts is small, or nonexistent" (p. 66). But the critics claimed that social bonding theory begins with the assumption that the same values are shared by all members of society. Given this assumption, the critics asked how Hirschi could have come to any other conclusion.

Gibbons and Krohn (1991) pointed out that Braithwaite (1981) believed there should have been a distinction made between the working, or lower, class subgroups. Competing theories, especially strain and nonempirical Marxist/critical theories, rely on class to explain crime (Jones, 2017) and claim that delinquency distribution is concentrated in the lower class. Their criticism of Hirschi, then, is that he failed to think the class variable through. Empey (1978) wrote that Hirschi was "disinclined to see value conflicts in society as being responsible for an individual's insensitivity to the wishes of others" (p. 230). Akers (1973) a social learning theorist, believed that Hirschi should be faulted for not giving credence to the strength of sanctions in the socialization process which molds the youth's commitment to conformity. The sanctions range from those applied by the significant others mentioned by Hirschi to the sanctions imposed by the state to control illegal behavior.

What this meant, according to Empey (1978), was that many of the factors contributing to the social class relationship to delinquency were unexplained by Hirschi's social bonding theory. One such factor, according to Empey (1978) was the influence of social class on self-reported 
versus official police crime data. This is another reason, in addition to the methodological faults identified earlier, that positivistic criminologists were reluctant to accept this theory. Bytheway and May (1971) picked up on the lack of answers to the social class questions. On this issue, they stated that criminologists' efforts to study this "have been rewarded by mystification rather than clarification" (Bytheway \& May, 1971, p. 585). Is society characterized by similar values or by standards and expectations which are class competitive? Why did Hirschi drop the class-delinquency association for blacks? Bytheway and May (1971) believed that Hirschi's argument for a negative association between social class and delinquency was weakened by this omission. Is it intellectual preparation or the disadvantage of class position that is correlated to school performance and the development of school bonds?

Kempf (1993) also worried about the generalizability of Hirschi's findings across social categories. The assumption Hirschi made about people sharing a common definition of what is good and bad (Hirschi, 1969, p. 18-23) cannot be taken for granted, argued Kempf. "It depends on how 'delinquency' is defined," said Gibbons and Krohn (1991, p. 56). Hirschi failed to point out that delinquent behavior could be seen as a response to social inequality and conflicting rules. Morality is not self-evident, but Hirschi was disinclined to accept that, just as he could not see that value conflicts are responsible for people's insensitivity to others (Shoemaker, 1984). This related to the sixth major criticism social scientists had with Hirschi.

\subsection{Power}

Social conflict theorists are a vocal set of criminologists that arose in the "turbulent 1960s" when society was blaming the government or societal institutions like class structures for the rise in crime. They view society in conflict, rather than in consensus. They focus on the power differences between the upper and lower classes (Tibbetts, 2019). Some of these social conflict theorists argued that criminologists like Hirschi not only failed to explain the clash of social class interests and values, they claimed criminologists also failed to explain delinquency as resulting from differential access to and use of power. They thought Hirschi's assumptions on the degree of commitment (as he defined it) was inaccurate. They believed there was no consensual view of social order.

The "consensual" view espoused by Hirschi and other traditional criminologists, sought to preserve the existing order in an unequal and unjust society. Özbay and Özcan (2006) believed Hirschi's paradigm was "politically conservative" (p. 712). It is their "single purpose," said Quinney, 1974, p. 13). According to Quinney (1974), society is organized by the existence of ruling class power. This power controls the schools and the legislature to which commitment is expected. Hirschi, and other control theorists, according to this view, provided a misleading description of the causes of delinquency by assuming the sources of crime are "located in the person who violates the law rather than in the authority that defines behavior as criminal" (Quinney, 1974, P. 13). Deviance is a social status created by the manner in which youth are perceived, evaluated, graded, disciplined and controlled. The commitment, which Hirschi made one of the four elements of social bond, was really a set of "social norms of deference" (Turk, 1969, p. 41). School officials are rewarded for their part in 
the maintenance of social order and they, in turn, create and enforce the rules the youth admitted, in Hirschi's questionnaire, that they broke.

\subsection{Type of Deviancy}

The seventh, and next to last, criticism concerned the type of deviancy that Hirschi studied and they suggested that he did not carry his ideas far enough. His theory only dealt with petty offences and not more serious kinds of delinquency (Jones, 2017; Bernard, 1984; Agnew, 1985; Thio, 1978) where some critics (Hill \& Pollock, 2015; Krohm \& Massey, 1980; Agnew, 2005) suggested social bonding theory would not have been a good predictor of delinquency. As Kelly and Pink (1973) pointed out, the evidence did suggest that less serious offenses are strongly related to the element of commitment. But they thought Hirschi made a mistake when he said that juveniles would diversify their deviancy throughout their lives (Smith, Smith \& Noma, 1984). But even here, there has been considerable evidence that delinquents specialize in their criminal careers. Much of this specialization carries over into the more upper-class world of crime. Hagan (1983), a power-control theorist, claimed that Hirschi failed to carry the implications of social control theory to include this group (Hagan, 1983). He believed that Hirschi should not have limited his theory to just lower and middle-class adolescents.

\subsection{Development and Severance}

The last criticism with Hirschi's social control theory came from developmental, learning and conflict theorists. They believed that Hirschi failed to specify how the bonds of attachment, involvement, commitment and belief are actually formed or developed and consequently how reform from broken bonds could be explained (Jones, 2017). Wiatrowski (1978) wrote that Hirschi was "unable to distinguish between those delinquents who were initially bonded and those whose bond was weakened and those whose socialization was never completed" (p. 52). Conflict theorists Colvin and Pauly (1983) believed that the bonds developed out of the relationship between authorities and individuals. They believed that rather than taking a "unidimensional approach" (Jones, 2017, p. 239) in describing juveniles as being "weakly" or "strongly bonded" (Colvin \& Pauly, 1983, p. 519). Hirschi should have considered a combination of qualitative and quantitative measures of the types of bonding and their relationship to the types of power used by authorities (Colvin \& Pauly, 1983). Hirschi had no choice, they claimed, but to keep it simple after he began with the "uncritical notion of a 'conventional order,' shared by much of conventional criminology" (p. 519).

Developmental theorists claimed a major limitation to Hirschi's theory was an absence to macro changes in social structures and historical developments (Cullen, Agnew and Wilcox, 2014). They found Hirschi's work "largely astructural and ahistorical" (p. 228). The individual, according to Hirschi, is either bonded or unbonded. This makes the ideological jump from being unbonded to bonded and vice-versa (Meier, Burkett \& Hickman, 1984) difficult to explain. Hirschi's assumption also, according to structural-Marxists Colvin and Pauly (1983), led to his failure to specify how the bonds were developed or severed. They believed that the methods parents used in socializing and disciplining their children reflected the type of controls used on them at their workplace (Akers et al., 2017). 


\section{Summary}

Eight major criticisms of Hirschi's social bonding theory have been presented. The first was that he used five unsubstantiated assumptions to predicate a reductionist view of delinquency which failed to consider individualized motivation. Secondly, it was shown that his elements of the social bond were not validly or reliably measured because of his self-supported questionnaire data and the fact that he failed to prove that teachers, friends and parents represent the conventional social order. The construct of attachment was isolated for specific criticism. The third area faulted involved the administration and length of the questionnaire and Hirschi's failure to account for more than 25 percent of the variation between delinquents and nondelinquents. The unjustified dropping of women from his sample and the neglecting of race, delinquent peer influence and religion from his sample was the fourth criticism. Critics thought he should have included these variables because they would have provided further explication of the significance of social bonds.

The relationships of these social bonds to social class was another area critics believed were poorly explained by Hirschi. They claimed that the strength of sanctions in the socialization process was almost entirely overlooked by Hirschi. A related sixth omission was the significance of power in the labeling of delinquency and administration of justice. Critical theorists believed that law does not equitably serve the interests of all, and Hirschi, by avoiding this line of thought, provided, they claimed, a misleading theory of delinquency. The seventh problem with this theory was that he only dealt with "petty offenders" and then made the claim that juveniles would diversify their deviance throughout their careers. Hirschi also excluded the "upper class" deviant from his study. The last criticism was that having identified and defined four social bonds, Hirschi failed to explain how they developed, how they could be severed and how they could be repaired.

In short, despite the overwhelming empirical support of Hirschi's social bond theory (Tibbetts, 2018; Cullen et al., 2014), there were definite limitations found by the critics. This theory has been tested in whole or in part many times (e.g., Chui \& Chan, 2012; Hill and Pollock, 2015; Felson \& Staff, 2006; Agnew, 1985; Eve, 1978; Goodenow, 1993; Matsueda \& Anderson, 1998; Krohn \& Massey, 1980). Some of these tests have been negative, some supportive and some mixed. They show that the strength of the relationship between social bonding and delinquency ranges from low to moderate (Akers et al., 2017). They show that the bonds have "important direct effects" (Costello \& Vowell, 1999, p. 815) on conformity. Kempf (1993), in her review of Hirschi's early theory used a quote from Cohen stating that Hirschi's theory was "fertile but not yet fecund" (Posick, 2018. P. 102). Eventually, Hirschi, along with his student, Gottfredson, "radically abandoned" (Chriss, 2007, p. 700) the social bonding theory and replaced it with a self-control theory (Hirschi \& Gottfredson, 1990). Why did they do this? It had to be partly that they began to agree with some of the critics. After all, progress through thesis, antithesis, and thesis is the Hegelian nature of social science research. It was, as Hirschi (2004) explained, "after examining age distributions of crimes and analogous acts, Gottfredson and I reversed my original position, concluding that these acts are, after all, manifestations of low self-control on the part of the offender" (p. 540). 
Hirschi (2004) also admitted, however, that his social bonding theory and his self-control theory are closely linked, if not the same (Intravia et al., 2012). This type of conjoined theory has been referred to as a middle-range theory that mixes psychological and sociological perspectives (Akers et al., 2017).

\section{Conclusion}

In the late 1960s, the U. S. President's Commission on Law Enforcement and Administration of Justice (1967) stated that "Americans best hope for reducing crime is to reduce juvenile delinquency and youth crime" (p. 55). It was against this backdrop that Hirschi analyzed 1964 data from the Richmond (California) Youth Project to propose social bonding theory in his dissertation. Even though Hirschi's (1996) research methodology and data have been questioned (Akers, 1973; Box \& Ford, 1971) or summarily dismissed (Gibson, 1970), his influence and intellectual contributions to the understanding of juvenile delinquency will long endure in the academic world as his theories of social control and self-control continue to be taught, tested and analyzed. Even the new social bond/self-control version has not undermined the power and importance of the theory set forth in Hirschi's (1969) Causes of Delinquency (Unnever et al., 2009).

The question that remains, however, is whether Hirschi's (1969) insights have resulted in clear, manageable and practical policies that can be used by criminal justice practitioners to reduce delinquency. His theory should be appealing to criminal justice practitioners because of its straight forward and logical delinquency-prevention implications. Juveniles must be adequately socialized and develop a strong moral attachment to society through positive identification with family, law and school.

Lane (2018) recently claimed that today's at-risk and offending juveniles face many of the same issues that the 1960s youth encountered. She wrote that criminal justice practitioners and public policy makers have made significant progress in addressing delinquency because of the volumes of scholarly research. But she gave no credit to Hirschi despite her focusing on the detrimental influence of the youth's peers, neighborhood, families and schools. All of these were key to Hirschi's (1969) theory. Lane never mentioned Hirschi once although she argued for increased "commitment" and "attachment," two of Hirschi's elements of the social bond.

That said, studies around the world have continued to pay tribute to Hirschi's early paradigm. "It is a relatively convincing explanation for criminality" (Tibbetts, 2019, p. 176). Scholars test the significance of the social bond theory with more complex measures (Hill \& Pollock, 2015) and data that reflects today's youth values, attitudes and behaviors (Zaidi et al., 2016; Chui \& Chan, 2012; Cheung \& Cheung, 2008; Özbay \& Özcan, 2006; Vazony \& Killias, 2001) and they provide contemporary implications for schools, juvenile courts and parents. As noted by Lanier and Henry (2010), Hirschi's social bonding theory "still stands alone as a viable explanation for crime" (p. 196). Hirschi clearly forged a place in history as the foundation on which all of these polemics and challenges enabled his original work to expand with additional constructs. His theory has been refined by integration with other theories and has been developed as a more detailed explanation of the etiology of juvenile delinquency 


\section{Al Macrothink}

today that continues to influence practical policy reform and family, school and criminal justice interventions.

\section{References}

Adler, F., \& Laufer, W. S. (1995). The legacy of anomie theory. New Brunswick, NJ: Transaction Publishers.

Agnew, R. (1984). Autonomy and delinquency. Sociological Perspectives, 27(2), 219-240.

http://doi.org/10.2307/1389019

Agnew, R. (1985). Social control theory and delinquency: A longitudinal test. Criminology, 23(1), 47-61. http://doi.org/10.1111/j.1745-9125.1985.tb00325.x

Agnew, R. (1992). Foundations for a general strain theory of crime and delinquency. Criminology, 30(1), 47-88. http://doi.org/10.1111/j.1745-9125.1992.tb01093.x

Agnew, R. (2005). Why do criminals offend? A general theory of crime and delinquency. New York, NY: Oxford University Press.

Akers, R. (1964). Socioeconomic status and delinquent behavior: A retest. Journal of Research in Crime and Delinquency, 1(1), 38-46. http://doi.10.1177/002242786400100105

Akers, R. L. (1973). Deviant behavior: A social learning approach. Belmont, CA: Wadsworth Publishing Co.

Akers, R. L. (2000). Criminological theories: Introduction, evaluation, and application (3rd ed). Los Angeles, CA: Roxbury Publishing Co.

Akers, R.L., Sellers, C. S., \& Jennings, W. G. (2017). Criminological theories: Introduction, evaluation, and application (7th ed.). New York, NY: Oxford University Press.

Bainbridge, W. S., \& Crutchfield, R. D. (1983). Sex role ideology and delinquency. Sociological Perspectives, 26(3), 253-274. http://doi.org/10.2307/1389218

Bernard, T. J. (1984). Control criticisms of strain theories: An assessment of theoretical and empirical adequacy. Journal of Research in Crime and Delinquency, 21(4), 353-372. http://doi.10.1177/0022427884021004005

Boman, J. H., Ward, J. T., Gibson, C. L., \& Leite, W. L. (2012). Can a perceptual peer deviance measure accurately measure a peer's self-reported deviance? Journal of Criminal Justice, 40 (6), 463-471. http://doi.org/10.1016/j.jcrimjus.2012.07.003

Box, S., \& Ford, J. (1971). The facts don't fit: On the relationship between social class and criminal behavior. Sociological Review, 19(1), 31-52. http://doi.org/10.1111/j.1467 $-54 x .1971 . t b 00618 . x$

Braithwaite, J. (1981). The myth of social class and criminality reconsidered. American Sociological Review, 46:36-57. http://doi.10.2307/2095025

Bytheway, W. R., \& May, D. R. (1971). On fitting the 'facts' of social class and criminal 


\section{Macrothink}

Issues in Social Science

ISSN 2329-521X

2018, Vol. 6, No. 2

behavior: A rejoinder to Box and Ford. Sociological Review, 19(4), 585-607. http://doi.org /10.1111/j.1467-954X.1971.tb0064.x

Cernkovich, S. A. (1978). Evaluating two models of delinquency causation: Structural theory and control theory. Criminology, 16(3), 335-352. http://doi.10.1111/j.1745 -9125.1978.tb00096.x

Chambliss, W. J. (1976). Functional and conflict theories of crime: The heritage of Emile Durkheim and Karl Marx. In W.J. Chambliss and M. Mankoff (Eds.), Whose law? What order? (pp. 1-28). New York, NY: John Wiley.

Chesney-Lind, M. (1997). The female offender: Girls, women, and crime. Thousand Oaks, CA: Sage.

Chesney-Lind, M., \& Shelden, R. G. (2004). Girls, delinquency, and juvenile justice. Thousand Oaks, CA: Sage.

Cheung, N. W. T., \& Cheung, Y. W. (2008). Self-control, social factors, and delinquency: A test of the general theory of crime among adolescents in Hong Kong. Journal of Youth Adolescence, 37,412-430. http://doi.10.1007/s10964-007-9218-y

Chriss, J. J. (2007). The functions of the social bond. The Sociological Quarterly, 48(4), 689-712. http://doi.10.1111/j.1533-8525.2007.00097.x

Chui, W. H., \& Chan, H. C. O. (2012). An empirical investigation of social bonds and juvenile delinquency in Hong Kong. Child Youth Care Forum, 41,371-386. http://doi.10.1007/s10566-012-9172-z

Colvin, M., \& Pauly, J. (1983). A critique of criminology: Toward an integrated structural-Marxist theory of delinquency production. American Journal of Sociology, 89(3), 513-551. http://doi.org/10.1086/227904

Conger, R. (1976). Social control and social learning models of delinquency: A synthesis. Criminology, 14(1), 17-40. http://doi.org/10.1111/j.1745-9125.tb00002.x

Conklin, J. E. (1981). Criminology. New York, NY: Macmillan Publishing Co., Inc.

Costello, B. J., \& Vowell, P. R. (1999). Testing control theory and differential association: A reanalysis of the Richmond Youth Project data. Criminology, 37(4), 815-837. http://doi.org/10.111/j.1745-9125.1999.tb00506.x

Cressey, D. R. (1962). The development of a theory: Differential association. In M. E. Wolfgang, L. Savitz and N. Johnson (Eds.), The sociology of crime and delinquency. New York, NY: John Wiley.

Cretacci, M. A. (2002). Religion and social control theory: An expansion of Hirschis social bond. http://search.proquest.com/docview/305476858

Cullen, F. T., Agnew, R., \& Wilcox, P. (2014) Criminological theory; Past to present (5th ed.). New York, NY: Oxford University Press. 


\section{Al Macrothink}

Issues in Social Science

ISSN 2329-521X

2018, Vol. 6, No. 2

Dukes, L. R., \& Stein, A. J. (2001). Effects of assets and deficits on the social control of at-risk behavior among youth: A structural equations approach. Youth and Society, 32(3), 335-359. http://doi.org/10.1177/0044118X01032003003

Durkheim, E. (1965 [1912]). The elementary forms of religious life. New York, NY: The Free Press.

Durkheim, E. (1966). Suicide. (J. Spaulding and G. Simpson, Trans.) New York, NY: The Free Press.

Empey, L. T. (1978). American delinquency: Its meaning and construction. Homewood, Ill: The Dorsey Press.

Erickson, K. G., Crosnoe, R., \& Dornbusch, S. M. (2000). A social process model of adolescent deviance: Combining social control and differential association perspectives. Journal of Youth and Adolescence, 29(4), 395-425. http://doi.org/10.1023/A:1005163724952

Eve, R. A. (1978). A study of the efficacy and interactions of several theories for explaining rebelliousness among high school students. Journal of Criminal Law and Criminology, 69(1), 115-125. http://doi/9901-4169/78/6901-0115S02.00/0

Felson, M., \& Eckert, M. (2018). Introductory criminology: The study of risky situations. New York, NY: Routledge.

Felson, R. B., \& Staff, J. (2006). Explaining the academic performance-delinquency relationship. Criminology, 44(2), 299-320. http://doi.org/10.1111/j.1745-9125.2006.00050.x

Gibbons, D. C. (1979). The criminological enterprise: Theories and perspectives. Englewood Cliffs, NJ: Prentice-Hall.

Gibbons, D. C. (1994). Talking about crime and criminals: Problems and issues in theory development in criminology. Englewood Cliffs, NJ: Prentice-Hall.

Gibbons, D. C., \& Krohn, M. D. (1991). Delinquent behavior (5th ed). Englewood Cliffs, NJ: Prentice-Hall.

Gibson, H. B. (1970). Book Review [Review of Causes of delinquency, by T. Hirschi]. Sociological Review, 18(3), 452-453. http://doi.10.1111/j.1467-954X.1970.tb00475.x

Goodenow, C. (1993). The psychological sense of school membership among adolescents: Scale development and educational correlates. Psychology in the Schools, 30(1), 79-90. http://doi.10.1002/1520-6807(199301)30:1<79::AID-PITS2310300113>3.0.CO;2-X

Gove, W. R. (1975). The labeling of deviance: Evaluating a perspective. New York, NY: Sage Publications.

Hagan, J. (1989). Structural criminology. New Brunswick, NJ: Rutgers University Press.

Hill, M. C., \& Pollock, W. (2015). Was Hirschi right? A national-level longitudinal examination of religion as a social bond. Deviant Behavior, 36(10), 783-806. http://doi. $10.1080 / 01639625.2014 .977149$ 


\section{Macrothink}

Issues in Social Science

ISSN 2329-521X

2018, Vol. 6, No. 2

Hindelang, M. J. (1973). Causes of delinquency: A partial replication and extension. Social Problems, 20(4), 471-487. http://doi.10.1525/sp.1973.20.4.03a00070

Hirschi, T. (1969). Causes of delinquency. Berkeley, CA: University of California Press.

Hirschi. T. (2004). Self-control and crime. In R. F. Baumeister and K. Vohs (Eds.) Handbook of self-regulation: Research, theory, and application. (pp.537-552). New York: Guilford Press.

Hirschi, T. (2011). The craft of criminology: Selected papers. J. H. Laub (Ed.). New Brunswick, NJ: Transaction Publishers.

Hirschi, T., \& Stark, R. (1969). "Hellfire and delinquency." Social Problems, 17(2), 201-213. http://doi.10.2307/7999866

Hobbes, T. (1957 [1651]). Leviathan. Oxford, UK: Basil Blackwell.

Intravia, J., Jones, S., \& Piquero, A. R. (2012). The roles of social bonds, personality, and perceived costs: An empirical investigation into Hirschi's "new" control theory. International Journal of Offender Therapy and Comparative Criminology, 56(8), 1182-1200. http://doi.10.1177/0306624X11422998

Jenson, G. F. (2003). Social control theories. In R. A. Wright and M. Miller (Eds.). Encyclopedia of criminology (pp. 1540-1545). Chicago, IL: Fitzroy Dearborn Publishers.

Jones, S. (2017). Criminology (6th ed.). Oxford, UK: Oxford University Press.

Kelly, D. H., \& Pink, W. T. (1973). School commitment, youth rebellion and delinquency. Criminology, 10(4), 473-485. http://doi.10.1111/j.1745-9125.1973.tb00577.x

Kempf, K. L. (1993). The empirical status of Hirschi's control theory. In F. Adler and W. S. Laufer (Eds.), New directions in criminological theory: Advances in criminal theory (pp. 143-185). New Brunswick, NJ: Transaction Publishers.

Krohn, M. D, \& Massey, J. L. (1980). Social control and delinquent behavior: An examination of the elements of the social bond. Sociological Quarterly, 21(4), 529-543. Retrieved from http:www.jstor.org/stable/4106137

Lane, J. (2018). Addressing juvenile crime: What have we learned, and how should we proceed? Criminology \& Public Policy, 17(2), 283-307. http://doi.10.111/1745-9133.12362

Lanier, M. M., \& Henry, S. (2010). Essential criminology (3rd ed). Boulder, CO: Westview Press.

Lemert, E. (1970). Reviewed Works [Review of Causes of delinquency by T. Hirschi. American Journal of Sociology, 76(1), 188-191. Retrieved from http:www.jstor.org/stable 12775456

Lilly, J. R., Cullen, F. T., \& Ball, R. A. (2011). Criminological theory: Context and consequences (5th ed). Thousand Oaks, CA: Sage Publishing. 


\section{Al Macrothink}

Issues in Social Science

ISSN 2329-521X

2018, Vol. 6, No. 2

Linden, E., \& Hackler, J. C. (1973). Affective ties and delinquency. Pacific Sociological Review, 16(1), 27-46. http://doi.org/10.2307/1388652

Little, C. B. (1983). Understanding deviance and control: Theory research and social policy. Itasca, IL: Peacock Publishers.

Matsueda, L., \& Anderson, K. (1998). The dynamics of delinquent peers and delinquent behavior. Criminology, 36, 269-308. http://doi.0.1111/j.1745-9125.1998.tb01249.x

Meiler, R., Burkett, S., \& Hickman, C. (1984). Sanctions, peers and deviance: Preliminary models of a social control process. Sociological Quarterly, 25(1), 67-82. http://doi.10.1111/j.1533-8525.1984.tb02239.x

Merton, R. K. (1938). Social structure and anomie. American Sociological Review, 3(5), 672-682. http://doi.10.2307/2084686

Messerschmidt, J. W. (1993). Masculinities and crime: Critique and reconceptualization of theory. Lanham, MD: Rowman \& Littlefield.

Morris, R. R. (1964). Female delinquency and relational problems. Social Forces, 43(1), 82-89. http://doi.10.2307/2575969

Özbay, O., \& Özcan, Y. Z. (2006). A test of Hirschi's social control bonding theory: Juvenile delinquency in the high schools of Ankara, Turkey. International Journal of Offender Therapy and Comparative Criminology, 50(6), 711-726. http://doi.10.1177 /0306624X05283525

Özbay, O., \& Özcan, Y. Z. (2008). A test of Hirschi's social bonding theory: A comparison of male and female delinquency. International Journal of Offender Therapy and Comparative Criminology, 52 (2), 134-157. http://doi.10.1177/0306624X07309182

Pratt, T. C., Gau, J. M., \& Franklin, T. W. (2011). Key issues in criminology and criminal justice. Thousand Oaks, CA: Sage.

Posick, C. (2018). The development of criminological thought: Context, theory, and policy. New York, NY: Routledge.

Quinney, R. (1974). Criminal justice in America. Boston, MA: Little, Brown.

Rankin, J. H., \& Kern, R. (1994). Parental attachments and delinquency. Criminology, 32(4), 495-515. http://doi.org/10.1111/j.1745-9125.1994.tb01163.x

Rosenfeld, R. (2018). Studying crime trends: Normal science and exogenous shocks. Criminology 56(1), 5-26. http://doi. 10.1111/1745-9125.12170

Shoemaker, D. J. (1884). Theories of delinquency: An examination of explanations of delinquent behavior. New York, NY: Oxford University Press.

Smith, D. R., Smith, W. R., \& Noma, E. (1984). Delinquent career-lines: A conceptual link between theory and juvenile offenses. Sociological Quarterly, 25(2), 155-172. http://doi.111/j.1533-8525.1984.tb00180.x 


\section{I Macrothink}

Sutherland, E. H. (1934). Principles of criminology (2nd ed.). Philadelphia, PA: Lippencott.

Sykes, G. M., \& Matza, D. (1957). Techniques of neutralization: A theory of delinquency. American Sociological Review, 22(6), 664-670. http://doi.10.2307/2089195

Thio, A. (1978). Deviant Behavior. Boston, MA: Houghton Mifflin.

Tibbetts, S. G. (2019). Criminological theory: The essentials. (3rd ed.). Thousand Oaks, CA: Sage Publications.

Tittle, C. R., Villemez, W. J. and Smith, D. A. (1978). The myth of social class and criminality: An empirical assessment of the empirical evidence. American Sociological Review, 43(5), 643-656. http://doi.org/10.2307/2094541

Turk, A. (1969). Criminality and the legal order. Chicago, IL: Rand McNally.

Unnever, J. D., Cullen, F. T., Mathers, S. A., McClure, T. E., \& Allison, M. C. (2009). Racial discrimination and Hirschi's Criminological classis: A chapter in the sociology of knowledge. Justice Quarterly, 26(3), 377-409. http://doi.10.1080/07418820802506180

U. S. President's Commission on Law Enforcement and Administration of Justice. (1967). The challenge of crime in a free society. Washington, DC: Government Printing Office.

Vazsonyi, A. T., \& Killias, M. (2001). Immigration and crime among youth in Switzerland. Criminal Justice and Behavior, 329-366. http://doi.org/10.1177/0093854801028003004

Vetter, H. J., \& Silverman, I. J. (1986). Criminology and crime. New York, NY: Harper and Row, Publishers.

Vold, G. B., \& Bernard, T. J. (1986). Theoretical criminology (3rd ed). Oxford, UK: Oxford University Press.

Wiatrowski, M. D. (1978). Social control theory and delinquency. Retrieved from http://pdxscholar.library.pdx.edu/open_access_etds

Wiatrowski, M. D., \& Anderson, K. L. (1987). The dimensionality of the social bond. Journal of Quantitative Criminology, 3(1), 65-81. http://dooi.org/10.1007/BF01065201

Wong, S. K. (2005). The effects of adolescent activities on delinquency: A differential involvement approach. Journal of Youth and Adolescence, 34(4), 321-333. http://doi.10.1007/s10964-005-5755-4

Zaidi, A. U., Couture-Carron, A., \& Maticka-Tyndale, E. (2016). "Should I or should I not"?: An exploration of South Asian youths' resistance to cultural diversity. International Journal of Adolescents and Youth, 21(2), 232-251. http://doi.org/10.1080/02673843.2013.836978 